\title{
Vitamin D in Aging and Chronic Illness
}

\section{Veronica A. Ralls' ${ }^{1}$ Alaina P. Boyer ${ }^{2}$ and Consuelo H. Wilkins ${ }^{1,2 *}$}

${ }^{1}$ Meharry Medical College, Vanderbilt University Medical Center, Nashville, TN, USA

${ }^{2}$ Meharry-Vanderbilt Alliance, Vanderbilt University Medical Center, Nashville, TN, USA

\begin{abstract}
The role of vitamin $\mathrm{D}$ in calcium homeostasis and its impact on bone is well characterized and validated; however the role vitamin D plays in non-bone physiology is less concrete. The Vitamin D Receptor (VDR) is expressed throughout the body and regulates many cellular processes. This discovery has led to vigorous research of vitamin $D$ and the role it plays in many illnesses, especially those of high prevalence in the United States. Vitamin D deficiency has been implicated in numerous health conditions and thus is an intriguing target for therapeutic intervention. Studies examining the therapeutic effects of vitamin $D$ in chronic disease and disease prevention have yielded conflicting results. Additionally, many publications on vitamin $D$ result from studies in which vitamin $D$ was not the primary focus. Given the increasing interest in the non-bone effects of vitamin D, we will review and summarize the recent literature related to older adults, a group with significantly increased risk of vitamin $D$ deficiency. Older adults have substantial morbidity and mortality due to dementia, cancer and heart disease, all of which have been linked to vitamin $D$ deficiency. We will explore current evidence of the expression of VDR and the effects of exposure to vitamin $D$ that might impact these illnesses among older adults. We will review the most recent research on cognitive function and depression as a result of vitamin $D$ deficiency. Through this work we aim to summarize the current data that sheds light on the possibility of clinical application of vitamin $\mathrm{D}$ therapy.
\end{abstract}

Keywords: Vitamin D; Heart disease; Cancer

\section{Introduction}

The purpose of this review it to summarize the evidence supporting the role of vitamin $D$ in cognitive and physical health. We will summarize hormonal characteristics and describe the biological and physiological actions of vitamin $\mathrm{D}$, the effects of vitamin $\mathrm{D}$ deficiency on cognitive and physical functions as well as depressive symptomatology. Finally, we will discuss the current state of evidence of the role of vitamin $D$ deficiency in cardiovascular disease, cancer, and diabetes. Table 1 summarizes important information from each of the clinical studies reviewed, including a list of primary outcomes of interest.

\section{Vitamin D}

\section{Hormone}

Vitamin D is an essential sterol hormone which undergoes bioactivation in a tightly regulated process. In response to sunlight exposure, 7-dehydrocholesterol is converted to previtamin D3 in the skin by photolytic conversion which is then followed by thermal isomerization to form vitamin D3 [1]. Vitamin D3 is released into the blood where it is hydroxylated at carbon 25 primarily in the liver, although skin, intestine and kidney have been reported to catalyze this hydroxylation [2]. Of note, 25-hydroxyvitamin D (calcidiol) levels increase in proportion to oral vitamin $\mathrm{D}$ intake so plasma 25-hydroxyvitamin D levels are commonly used as an indicator of vitamin $\mathrm{D}$ status [1]. A second hydroxylation occurs by 1 - $\mathrm{a}$-hydroxylase, primarily in the kidney, to form 1,25-dihydroxyvitamin D (calcitriol), the biologically active and hormone form of vitamin D (Figure 1). The presence of 1a-hydroxylase in the human brain has been confirmed suggesting a role of vitamin D in the brain [3]. Both Parathyroid Hormone $(\mathrm{PTH})$ and serum calcium regulate renal synthesis of calcitriol in a feed-back loop to control bone mineral homeostasis.

Because dietary sources of vitamin D are limited, well-nourished people are still at risk for vitamin D deficiency. Foods with vitamin $\mathrm{D}$ include fatty fish such as sardines and salmon, liver, and egg yolks. Some foods, primarily milk and dry cereal, are fortified with vitamin D. Interestingly, the amount of vitamin $\mathrm{D}$ in fortified milk was determined based on the needs of preschool-aged children, not adults, and the amount is targeted to prevent rickets. Foods fortified with vitamin D often contain between 100 and $200 \mathrm{IU}$ per serving while vitamin $\mathrm{D}$ that is generated from sunlight is estimated to be 3,000 to 5,000 units/day [4]. Vitamin D3 (cholecalciferol), from an animal source and vitamin D2 (ergocalciferol) from yeast and plants, can be administered orally and are subsequently converted to active vitamin D metabolites. Older adults, individuals with darker skin and those with extreme obesity $\left(\mathrm{BMI}>40 \mathrm{~kg} / \mathrm{m}^{2}\right)$ are at increased risk for vitamin D deficiency.

\section{Biological and physiological action}

The biologic actions of vitamin D may be considered as the classical and non-classical vitamin $\mathrm{D}$ responsive tissues. The classical tissues include the kidney, bone, parathyroid gland and intestine, which interact to maintain extracellular calcium homeostasis [2]. The nonclassical tissues include immune, adipose, reproductive, endocrine, brain, liver, muscle, and skin [5-7]. The importance of vitamin D in bone mineralization and formation is well known and vitamin $\mathrm{D}$ deficiency alone can result in rickets, osteomalacia, and osteoporosis. In the small bowel, vitamin D improves absorption of calcium and phosphorus. Initially, calcium uptake is highly dependent on vitamin $\mathrm{D}$ [4]. Additionally, vitamin $\mathrm{D}$ is a potent modulator of parathyroid function. Vitamin D deficiency results in hyperparathyroidism and conversely, vitamin D administration inhibits PTH synthesis [8]. The expression of 1a-hydroxylase in numerous cell types unrelated to calcium homeostasis including cells of the central nervous system [9], suggests an autocrine or paracrine function of vitamin $\mathrm{D}$ in these tissues [3]. The non-classical vitamin $\mathrm{D}$ responsive tissues are unrelated to its effect on calcium homeostasis. These tissues include neurons, muscle, activated T cells, islet cells and aortic endothelial cells (Figure 1).

*Corresponding author: Consuelo $\mathrm{H}$. Wilkins, Vanderbilt University School of Medicine, Nashville, TN, USA, Tel: 615-963-2820; Fax: 615-320-9457; E-mail: consuelo.h.wilkins@meharry-vanderbilt.org

Received July 02, 2013; Accepted September 09, 2014; Published September 16, 2014

Citation: Ralls VA, Boyer AP, Wilkins CH (2014) Vitamin D in Aging and Chronic Illness. Vitam Miner 3: 125.

Copyright: @ 2014 Ralls VA, et al. This is an open-access article distributed under the terms of the Creative Commons Attribution License, which permits unrestricted use, distribution, and reproduction in any medium, provided the original author and source are credited. 


\begin{tabular}{|c|c|c|c|c|}
\hline Reference & Sample & $\mathbf{N}$ & Measurements & Results \\
\hline \multicolumn{5}{|c|}{ Cognitive Function } \\
\hline BKipen [25] & $\begin{array}{l}\text { Community-dwelling older women with mild } \\
\text { dementia and NC }\end{array}$ & 20 & $\begin{array}{l}\text { Bone density, PTH, } \\
\text { Vitamin } \mathrm{D}_{3}\end{array}$ & $\begin{array}{l}\text { Bone density: NSD between groups } \\
\text { PTH: levels were higher in dementia group }(P<.01) \\
\text { Vitamin } D_{3} \text { : levels were lower in the dementia group } \\
(P<.01)\end{array}$ \\
\hline BOgihara [26] & $\begin{array}{l}3 \text { groups of hospitalized women; NC, DAT, } \\
\text { VaD }\end{array}$ & 60 & $\begin{array}{l}\text { Ca levels, PTH, Vitamin } \\
\mathrm{D}_{3}\end{array}$ & $\begin{array}{l}\text { DAT group showed a significant decrease in } \mathrm{Ca}(\mathrm{P}<.01) \\
\text { and increase in } \mathrm{PTH}(\mathrm{P}<.05) \text { compared to } \mathrm{NC}\end{array}$ \\
\hline BSato [27] & $\begin{array}{l}\text { Nursing home dwelling women with DAT } \\
\text { and NC controls from the community }\end{array}$ & 46 & BMD, Vitamin $\mathrm{D}_{3}, \mathrm{PTH}$ & $\begin{array}{l}\text { BMD, vitamin } D_{3} \text { levels were lower in DAT }(P<.0001) \text {; PTH } \\
\text { was lower in DAT }(P=.001)\end{array}$ \\
\hline BJorde [28] & $\begin{array}{l}\text { Adults, with secondary hyperparathyroidism } \\
\text { (SHPT) and healthy controls }\end{array}$ & 84 & $\begin{array}{l}\text { Cognitive test of working } \\
\text { memory, information } \\
\text { processing, memory, } \\
\text { language, executive } \\
\text { function }\end{array}$ & $\begin{array}{l}\text { SHPT group had poorer performance on Digit Span } \\
\text { Forward }(\mathrm{P}<.01) \text { : Stroop Test }(\mathrm{P}<.05) \text {, Word Association } \\
\text { Test }(\mathrm{P}<.01) \text { relative to controls }\end{array}$ \\
\hline BWilkins [15] & $\begin{array}{l}\text { African American and European American } \\
\text { older adults with NC or mild cognitive } \\
\text { impairment }\end{array}$ & 60 & $\begin{array}{l}\text { Vitamin } D_{3} \text {, General } \\
\text { cognitive function }\end{array}$ & $\begin{array}{l}\text { Lower vitamin } D_{3} \text { levels were associated with poorer } \\
\text { cognitive performance }(P<.01) \text {; African Americans had } \\
\text { lower vitamin } D_{3} \text { levels }(P<.0001)\end{array}$ \\
\hline \multicolumn{5}{|l|}{ Depression } \\
\hline BPrzybelski [31] & $\begin{array}{l}\text { Chart review of clinic records of older adult } \\
\text { patients referred for memory loss }\end{array}$ & 80 & $\begin{array}{l}\text { Vitamin } D_{3} \text {, General } \\
\text { cognitive function }\end{array}$ & $\begin{array}{l}\text { Vitamin } D_{3} \text { levels were positively correlated with MMSE } \\
\text { performance }(P=.006)\end{array}$ \\
\hline BWilkins [16] & Participants with NC or mild AD & 80 & $\begin{array}{l}\text { Vitamin } D_{3} \text {, General } \\
\text { cognitive function }\end{array}$ & $\begin{array}{l}\text { Vitamin } D_{3} \text { deficiency was not predictive of } A D(P=.33) \text {; } \\
\text { was associated with poorer SBT performance }(P=.04) \text {; } \\
\text { higher CDR Sum of Boxes }(P=.02)\end{array}$ \\
\hline BOren [34] & $\begin{array}{l}\text { Adults with SAD and age-and-sex matched } \\
\text { controls }\end{array}$ & 30 & $\begin{array}{l}\text { Vitamin } D_{3} \text { levels with and } \\
\text { without light therapy }\end{array}$ & $\begin{array}{l}\text { NSD in vitamin } D_{3} \text { between groups or between light } \\
\text { conditions }(P>.05)\end{array}$ \\
\hline BLapid [36] & Primary care patients, older adults & 1,618 & $\begin{array}{l}\text { Vitamin } D_{3} \text { depression } \\
\text { diagnosis }\end{array}$ & $\begin{array}{l}\text { Lower vitamin } D_{3} \text { levels were associated with increased } \\
\text { risk for depression }(P=.01)\end{array}$ \\
\hline BSchneider [37] & $\begin{array}{l}\text { Adult schizophrenia patients, alcohol } \\
\text { addiction patients, patients with major } \\
\text { depression, and NC }\end{array}$ & 34 & $\begin{array}{l}\text { Vitamin } \mathrm{D}_{3} \text { PTH, Calcium, } \\
\text { Phosphate }\end{array}$ & $\begin{array}{l}\text { Vitamin } D_{3} \text { levels were lower in psychiatric patients than } \\
N C(P<.01)\end{array}$ \\
\hline CHoogendijk [39] & Community-dwelling older adults & 1,282 & Vitamin $\mathrm{D}_{3}, \mathrm{PTH}, \mathrm{CES}-\mathrm{D}$ & $\begin{array}{l}\text { Lower vitamin D3 levels were associated with depression } \\
\text { severity }(P<.001), P T H \text { levels were positively associated } \\
\text { with depression }(P=.003)\end{array}$ \\
\hline${ }^{A}$ Gloth [42] & $\begin{array}{l}\text { Adults with SAD who received Vitamin } D_{3} \\
(1000 \mathrm{IU}) \text { supplementation or phototherapy }\end{array}$ & 15 & $\begin{array}{l}\text { Depression, Vitamin } D_{3} \\
\text { levels }\end{array}$ & $\begin{array}{l}\text { Vitamin } D_{3} \text { group improved on all depression outcomes } \\
(P<.05) \text {, vitamin } D_{3} \text { levels improved in both groups } 74 \% \\
\text { vitamin } D \text { group, } p<0.005 \text { and } 36 \% \text { phototherapy group, } \\
P<0.01\end{array}$ \\
\hline DLansdowne [43] & $\begin{array}{l}\text { Healthy adults received Vitamin D3 } \\
\text { supplementation }(400 \mathrm{IU} / \mathrm{d}, 800 \mathrm{IU} / \mathrm{d} \text {, } \\
\text { placebo) }\end{array}$ & 44 & $\begin{array}{l}\text { Vitamin } D_{3} \text { levels, Positive } \\
\text { and Negative Affect }\end{array}$ & $\begin{array}{l}\text { Vitamin } D \text { groups expressed enhanced positive affect } \\
\text { relative to controls }(P<.001)\end{array}$ \\
\hline \multicolumn{5}{|c|}{ Physical Function } \\
\hline BPeterson [44] & Community-dwelling older adults & 159 & Falls, Motor function, & $\begin{array}{l}\text { Fallers had lower vitamin } D_{3} \text { levels }(P<.01) \text {, NSD in motor } \\
\text { function }(P>.05)\end{array}$ \\
\hline 'Sato [46] & $\begin{array}{l}\text { Parkinson's disease (PD) patients and } \\
\text { patients with vascular Parkinsonism (VP) } \\
\text { who received ergocalciferol (1200 IU) }\end{array}$ & 178 & $\begin{array}{l}\text { Fall, muscle strength, and } \\
\text { hip fracture incidence }\end{array}$ & $\begin{array}{l}\text { The number of falls decreased in the VP patients } \\
(P<.0001) \text {, hip fractures caused by falls occurred in seven } \\
\text { cases in the PD group, and in one case in the VP group, } \\
\text { increase in muscle strength occurred in both groups } \\
(P<.001)\end{array}$ \\
\hline 'D Dukas [47] & $\begin{array}{l}\text { Older adults at increased risk for falls who } \\
\text { received alfacalidol }(1 \mu \mathrm{g})\end{array}$ & 237 & $\begin{array}{l}\text { Timed up and Go Test } \\
\text { (TUG), Tandem Stand } \\
\text { Test,(TST) Chair Rising } \\
\text { Test (CRT), Falls }\end{array}$ & $\begin{array}{l}\text { Increased muscle power (TUG, CRT)and balance (TST), } \\
\text { and a decrease in falls (all P-values }<.0001 \text { ) was observed } \\
\text { after supplementation }\end{array}$ \\
\hline 'Schacht [48] & $\begin{array}{l}\text { Older adults with reduced bone mass who } \\
\text { received alfacalidol }(1 \mu \mathrm{g})\end{array}$ & 2,097 & $\begin{array}{l}\text { TUG, TST, CRT, fear } \\
\text { of falls }\end{array}$ & $\begin{array}{l}\text { Improvement in all muscle tests was observed }(\mathrm{P}<.0001) \\
\text { after supplementation }\end{array}$ \\
\hline ASanders [49] & $\begin{array}{l}\text { Community-dwelling older women who } \\
\text { received cholecalciferol }(500,000 \mathrm{IU} / \\
\text { yearly) or placebo }\end{array}$ & 2,256 & $\begin{array}{l}\text { Falls and fractures } \\
\text { (radiologically confirmed) }\end{array}$ & $\begin{array}{l}\text { Treatment group experienced } 15 \% \text { more falls }(P=.03) \text { and } \\
26 \% \text { more fractures }(P=.04) \text { than the placebo group }\end{array}$ \\
\hline BPeterson [51] & Parkinson's disease patients & 40 & $\begin{array}{l}\text { Balance function, Unified } \\
\text { Parkinson's Disease } \\
\text { Rating Scale (UPDRS) }\end{array}$ & $\begin{array}{l}\text { Vitamin } D_{3} \text { levels were inversely correlated with } P D \\
\text { severity }(P=.04) \text {, positively correlated with automatic } \\
\text { posture responses to backwards translation }(P<.05) \text {, } \\
\text { specifically with response strength and stance } \\
\text { weight }(P<.05)\end{array}$ \\
\hline AStein [52] & $\begin{array}{l}\text { Community-dwelling older adults and } \\
\text { participants with mild-to-moderate cognitive } \\
\text { impairment (MMSE score } 12-24) \text {, all } \\
\text { received vitamin } D_{2} \text { supplementation }(1000 \\
\text { IU/d/8 wk), then randomized to } 6000 \mathrm{IU} / \mathrm{d} / 8 \\
\text { wk (high dose group) or placebo), }\end{array}$ & 95 & $\begin{array}{l}\text { Disability assessment } \\
\text { in dementia (DAD) } \\
\text { questionnaire }\end{array}$ & NSD in disability after high dose $(6000 \mathrm{IU})(\mathrm{P}>.05)$ \\
\hline
\end{tabular}




\begin{tabular}{|c|c|c|c|c|}
\hline \multicolumn{5}{|c|}{ Cardiovascular Disease } \\
\hline${ }^{B}$ Melamed [56] & Adults $\geq 20$ years old & 13,331 & $\begin{array}{l}\text { Vitamin } \mathrm{D}_{3} \text { incidence of } \\
\text { cancer, cardiovascular } \\
\text { disease, all-cause } \\
\text { mortality }\end{array}$ & $\begin{array}{l}\text { Lowest quartile of vitamin } D_{3} \text { was associated with a } 26 \% \\
\text { increased rate of all-cause mortality }(1.26,95 \% \mathrm{Cl} 1.08 \text { - } \\
1.46)\end{array}$ \\
\hline AForman [57] & $\begin{array}{l}\text { African American adults aged } 30-80 \text { years } \\
\text { who were randomized in to a } 4 \text {-arm trial } \\
\text { (placebo, } 1000 \mathrm{IU}, 2000 \mathrm{IU}, 4000 \mathrm{IU} / \mathrm{d} \text { ) of } \\
\text { cholecalciferol }\end{array}$ & 283 & Blood pressure & $\begin{array}{l}\text { 1-ng/mL increase in plasma vitamin } D_{3} \text { levels were } \\
\text { associated } 0.2 \mathrm{mmHg} \text { reduction in systolic blood pressure } \\
(P=0.02)\end{array}$ \\
\hline ALarsen [58] & $\begin{array}{l}\text { Adults with hypertension who were } \\
\text { randomized to receive cholecalciferol }(3000 \\
\text { IU/placebo) }\end{array}$ & 112 & $\begin{array}{l}\text { Blood pressure (24-hour, } \\
\text { central), heart rate, pulse } \\
\text { wave velocity, central } \\
\text { augmentation, }\end{array}$ & $\begin{array}{l}\text { Cholecalciferol was associated with a decrease in central } \\
\text { systolic blood pressure }(P=.007) \text { relative to controls }\end{array}$ \\
\hline A Judd [59] & $\begin{array}{l}\text { African Americans } \geq 30 \text { years old with } 25 \geq \\
\text { vitamin D levels } \leq 75 \text { were randomized to } \\
\text { receive (placebo, calcitriol, or } 200,000 \text { IU } \\
\text { cholecalciferol) }\end{array}$ & 9 & Blood pressure & $\begin{array}{l}\text { Calcitriol group experienced a } 9 \% \text { decrease in systolic } \\
\text { blood pressure compared to placebo }(p<0.001) \text {. }\end{array}$ \\
\hline BSnijder [60] & Community-dwelling older adults & 1,205 & $\begin{array}{l}\text { Blood pressure, vitamin } \\
\mathrm{D}_{3} \text { PTH }\end{array}$ & $\begin{array}{l}\text { Vitamin } \mathrm{D}_{3} \text { levels were not associated with blood pressure } \\
(\mathrm{P}>.05), \mathrm{PTH} \text { was positively associated with blood } \\
\text { pressure }(\mathrm{P}<.05)\end{array}$ \\
\hline BJorde [61] & Adults aged $25-69$ years old & 27,159 & $\begin{array}{l}\text { Calcium intake, blood } \\
\text { pressure }\end{array}$ & $\begin{array}{l}\text { A negative association between calcium intake and } \\
\text { diastolic blood pressure }(\mathrm{P}<.05)\end{array}$ \\
\hline CJorde [62] & Adults aged $\geq 25$ years old & 4,125 & $\begin{array}{l}\text { Blood pressure, vitamin } \\
\mathrm{D}_{3} \text { levels }\end{array}$ & $\begin{array}{l}\text { Vitamin } D_{3} \text { levels were negatively associated with systolic } \\
\text { blood pressure }(P<.001) \text {, but did not predict future } \\
\text { hypertension }(P>.05)\end{array}$ \\
\hline AJorde [63] & $\begin{array}{l}\text { Overweight and obese adults aged } 21-70 \\
\text { years who were randomized for vitamin D } \\
\text { supplementation ( } 40000 \mathrm{IU} / \mathrm{wk}, 20000 / \mathrm{wk} \\
\text { placebo) }\end{array}$ & 438 & $\begin{array}{l}\text { Cardiovascular risk } \\
\text { factors (lipids, blood } \\
\text { pressure, glucose } \\
\text { metabolism ) }\end{array}$ & $\begin{array}{l}\text { After } 1 \text { year, NSD were found between the } 3 \text { groups for } \\
\text { measures of glucose metabolism or lipids }(P>.05) \text {, In the } \\
20000 \text { IU group there was a slight increase in systolic } \\
\text { blood pressure compared to placebo }(P<.05)\end{array}$ \\
\hline AWood [64] & $\begin{array}{l}\text { Postmenopausal women aged } 60-70 \\
\text { years were randomized for vitamin D } \\
\text { supplementation }(400 \mathrm{IU} / \mathrm{d}, 1000 \mathrm{IU} / \mathrm{d} \text {, } \\
\text { placebo) }\end{array}$ & 305 & $\begin{array}{l}\text { Cardiovascular disease } \\
\text { risk (lipids, insulin } \\
\text { resistance, markers } \\
\text { of inflammation, blood } \\
\text { pressure) }\end{array}$ & $\begin{array}{l}\text { After } 1 \text { year, daily supplementation with vitamin } D_{3} \text { had no } \\
\text { effect on cardiovascular disease risk }(P>.05)\end{array}$ \\
\hline${ }^{B}$ Correia [65] & $\begin{array}{l}\text { Patients with unstable angina in coronary } \\
\text { care units }\end{array}$ & 206 & $\begin{array}{l}\text { Cardiovascular death } \\
\text { during hospitalization }\end{array}$ & $\begin{array}{l}\text { Severe vitamin } D_{3} \text { deficiency was an independent } \\
\text { predictor of in-hospital cardiovascular mortality (OR: } 14 \text {, } \\
95 \% \mathrm{Cl}: 1.2 \text { to } 158,(P=.03)\end{array}$ \\
\hline \multicolumn{5}{|c|}{ Cancer Therapeutic } \\
\hline AWagner [70] & $\begin{array}{l}\text { Patients with prostate cancer (Gleason } \\
\text { score of } 6 \text { or } 7) \text { were randomized for } \\
\text { vitamin } D(400 \mathrm{IU} / \mathrm{d}, 10,000 \mathrm{IU} / \mathrm{d}, 40000 \\
\mathrm{IU} / \mathrm{d})\end{array}$ & 66 & $\begin{array}{l}\text { Serum vitamin } D_{3} \text { and } \\
\text { prostate tissue levels of } \\
\text { vitamin D metabolites, } \\
\text { proliferation marker Ki67 } \\
\text { (MIB-1) }\end{array}$ & $\begin{array}{l}\text { Dose dependent increase in prostate tissue and serum } \\
\text { levels of vitamin } D \text { metabolites }(P<.03) \text {, NSD in Ki67 levels } \\
\text { between groups }(P>.05)\end{array}$ \\
\hline \multicolumn{5}{|l|}{ Diabetes Control } \\
\hline ANikooyeah [73] & $\begin{array}{l}\text { Participants with T2D aged } 30-60 \text { years } \\
\text { were randomized to consume plain yogurt, } \\
\text { vitamin D-fortified yogurt (500 IU, } 150 \\
\mathrm{mg} \mathrm{CA}) \text {, or vitamin } D(500 \mathrm{IU})+\text { calcium- } \\
\text { fortified yogurt }(250 \mathrm{mg}) / 2 \times \mathrm{d} / 12 \mathrm{wks}\end{array}$ & 90 & Glycemic status & $\begin{array}{l}\text { Daily intake of vitamin D-fortified yogurt with or without } \\
\text { added calcium, improved glycemic status } \\
\text { in T2D participants }(P<.0001)\end{array}$ \\
\hline Avon Hurst [75] & $\begin{array}{l}\text { South Asian women aged } 23-68 \text { years, with } \\
\text { insulin resistance and vitamin D deficiency } \\
\text { were randomized to receive } 4000 \mathrm{IU} / \mathrm{d} \text { or } \\
\text { placebo for } 6 \text { months }\end{array}$ & 81 & Insulin resistance (IR) & $\begin{array}{l}\text { Improvements were seen in insulin sensitivity }(P=.003) \\
\text { and } I R(P=.02) \text { and fasting insulin decreased }(P=.02) \text { with } \\
\text { supplementation compared with placebo. }\end{array}$ \\
\hline AAljabri [76] & $\begin{array}{l}\text { Participants } \geq 12 \text { years old with T1D and } \\
\text { vitamin } D \text { deficiency were randomized to } \\
\text { receive } 4000 \mathrm{IU} / \mathrm{d} \text { or placebo for } 12 \text { weeks }\end{array}$ & 80 & Glycosylated hemoglobin & $\begin{array}{l}\text { Vitamin } D_{3} \text { supplementation was associated with improved } \\
\text { glycemic control }(P=.04)\end{array}$ \\
\hline 'Deleskog [77] & $\begin{array}{l}\text { Adults aged 33-56 years without T2D } \\
\text { followed for 8-10years }\end{array}$ & 2,378 & $\begin{array}{l}\text { Incidence of prediabetes, } \\
\text { T2D }\end{array}$ & $\begin{array}{l}\text { High vitamin } D_{3} \text { levels predicted a reduced risk of T2D in } \\
\text { individuals with prediabetes (OR } 0.38, C I 0.21,0.71 \text { ) }\end{array}$ \\
\hline AJorde [80] & $\begin{array}{l}\text { Adults aged } 21-75 \text { years, with T2D } \\
\text { treated with insulin and metformin were } \\
\text { randomized to receive supplementation } \\
\text { ( } 40000 \text { IU/wk or placebo) for } 6 \text { months }\end{array}$ & 36 & Glycemic control & $\begin{array}{l}\text { NSD from baseline values, NSD in change in glycemic } \\
\text { control }(P>.05)\end{array}$ \\
\hline
\end{tabular}

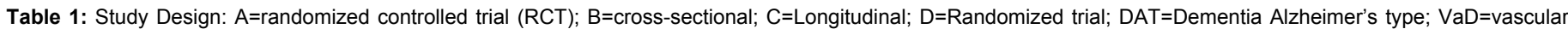
dementia; NSD=no significant difference; $N C=$ normal cognition; Ca=calcium; BMD=bone mineral density; PTH=parathyroid hormone; MMSE=Mini-mental State Examination; SBT=Short Blessed Test; CDR=Clinical Dementia Rating; SAD=Seasonal Affective Disorder; CES-D=Center for Epidemiologic Studies-Depression Scale; $\mathrm{IU}=$ International Units; T2D=type 2 diabetes; T1D= type 1 diabetes.

New mechanisms of vitamin D action have emerged and suggest effects on cell cycle and apoptotic processes which are critical events in the life cycle of a cell, but when deregulated can contribute to the pathology of disease development. Through a series of studies, VDR was found to suppress the oncogene c-myc while simultaneously inducing c-fos, two genes intricately involved in carcinogenesis [10].
Further validation is required to determine the exact mechanism of action in other model systems. Altered RNA expression of Bcl-2 genes has also been attributed to VDR activation by calcitriol in leukemia cells [11].

Vitamin D supplementation has been used to manage chronic 


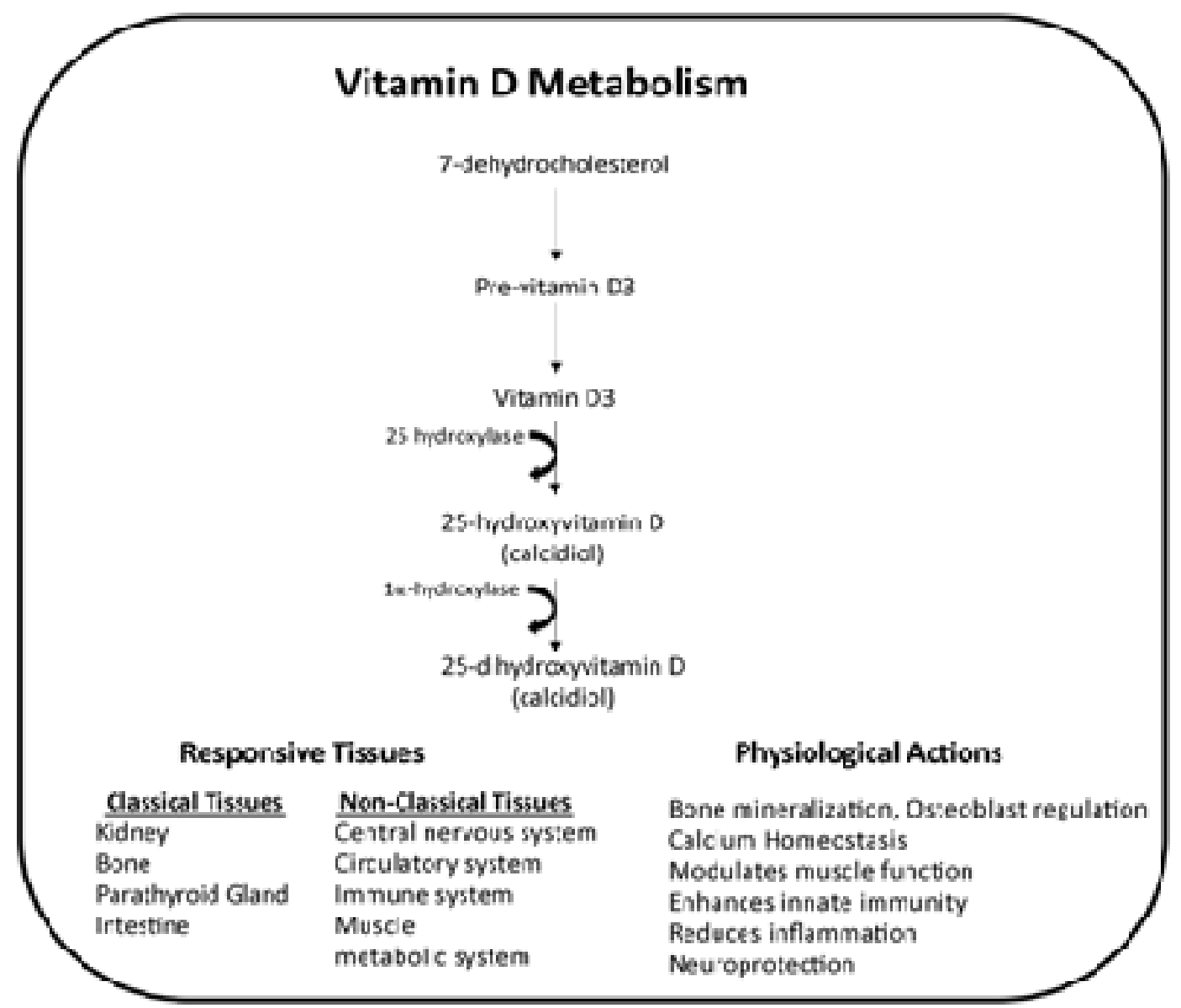

Figure 1: Vitamin D Metabolism and Actions. Vitamin D is metabolized in multiple steps and is expressed in many tissues. The classical actions of vitamin D, bone health and thyroid regulation most often occur in specific tissues. Other non-classical functions of vitamin D include cell proliferation, effects on inflammatory proteins and effects on cognitive function.

conditions and diseases in older adults. Although dosing remains controversial, there are benefits to using vitamin $\mathrm{D}$ to manage diseases and conditions common in older adults. Vitamin D has been shown to regulate calcium-phosphate homeostasis and stimulate bone growth through binding to VDR, which is expressed on osteoblasts and osteoclasts. This regulation makes the hormone a valuable supplement in older adults, a group more at risk for falls and fractures. Vitamin $\mathrm{D}$ deficiency has also been implicated in chronic inflammation known to co-exist with the aging process. Vitamin $\mathrm{D}$ has demonstrated antiinflammatory effects through inhibition of the activation of proinflammatory transcription factor NFk $\beta$ and interleukin-6 (IL-6) [12].

\section{Effects of Vitamin D Deficiency}

\section{Cognitive function}

Vitamin D plays an important role in brain function in vitro [13] and in vivo models [14]; recent evidence extends these findings to cognitive function in humans [15-17]. Vitamin D nuclear binding has been shown in the hippocampus [18], amygdala, and basal forebrain $[19,20]$ which are important areas in memory processing. Additionally, vitamin $\mathrm{D}$ dependent proteins are reduced in the hippocampal cells of humans with Alzheimer's disease (AD) [21] and transgenic mice with reduced vitamin $\mathrm{D}$ dependent proteins have impaired spatial learning [22]. Treatment with vitamin D stimulates choline acetyl-transferase in vitamin D-deficient rats [23] suggesting that vitamin D is important in the cholinergic systems associated with memory [24].

Observational studies report that levels of 25-hydroxyvitamin $\mathrm{D}$ are lower in participants with $\mathrm{AD}$ than non-demented controls [25-27]. The first paper to report an association between vitamin D deficiency and secondary hyperparathyroidism and impairment in neuropsychological function [28] in non-demented participants was published in 2006. This study found that participants with vitamin D deficiency and secondary hyperparathyroidism (without chronic renal disease) have significantly impaired performance in 3 of 14 cognitive tests including the Digit Span Forward, Stroop Test Part 1 and 2 and Word Association Test as well as significantly higher depression scores on the Beck Depression Inventory (BDI).

It is well established that persons with darker pigment, women and older adults are at greater risk of developing vitamin D deficiency. Further, African American women with vitamin D deficiency have worse outcomes than European women when performing cognitive assessments [15]. Secondary analysis of prospective research studies further confirms that poorer cognition is more strongly associated with vitamin $\mathrm{D}$ deficiency $[29,30]$. While these studies clearly support a relationship between cognition and vitamin $\mathrm{D}$ deficiency, the mechanism has not been fully elucidated.

Subsequently, other investigators have demonstrated that vitamin 
$\mathrm{D}$ levels are associated with cognitive function in non-demented $[16,31,32]$ and mildly demented [16] older adults. A recent finding in a cohort of community-dwelling older women further substantiates this relationship of vitamin D deficiency and cognition [33]. These findings suggest that a strong association exists between cognitive impairment and vitamin D status; therefore, supporting the hypothesis that vitamin $\mathrm{D}$ therapy may prevent or delay Age-Related Cognitive Decline (ARCD).

\section{Depression}

For years the association between vitamin $\mathrm{D}$ and mood disorders has been debated. Early studies found no association with depression and 1,25-dihydroxyvitamin D [34] but with the discovery of vitamin $\mathrm{D}$ receptors in the brain, researchers began to reconsider its role in mood disorders [35]. There have been several studies that support the notion that decreased levels of 25-hydroxyvitamin D levels are correlated with depression published in recent years. A recent study that enrolled a range of low to severely vitamin d deficient participants found the more severe the deficiency the greater the likelihood of depression $(\mathrm{OR}=2.45,95 \% \mathrm{CI}=1.24-4.64, \mathrm{p}=0.006)$ [36]. One specific study found a correlation between 25 -hydroxyvitamin D and Seasonal Affective Disorder (SAD) and depression [37,38]. Patients with a serum 25 -hydroxyvitamin $\mathrm{D}$ concentration below $16 \mathrm{ng} / \mathrm{ml}$ at a reference point also had increased Beck Depression Inventory (BDI) scores compared to patients with higher serum levels [35]. Numerous populations have been assessed for their depressive symptoms associated with decreased 25-hydroxyvitamin D. Older adults with reasonable health showed an association between decreased 25-hydroxyvitamin D levels and depression according to the BDI [39]. Cardiovascular patients with no history of depression developed symptoms of depression in the presence of low 25-hydroxyvitamin D concentrations ranging from 15$30 \mathrm{ng} / \mathrm{mL}$ [35]. Depression status and severity was also associated with decreased vitamin D and increased PTH in a large population based study [40].

Since SAD has been associated with winter months and sunlight deprivation [41], vitamin D deficiency has been considered a possible contributor to SAD. Additionally, vitamin $\mathrm{D}$ was found to be superior to phototherapy in SAD [42] and in a placebo-controlled trial vitamin D enhanced positive affect [43].

\section{Physical function}

The risk of falling and injury in the aging population is a fear expressed in many older adults. Research focused on vitamin $\mathrm{D}$ deficiency and falls in the elderly have demonstrated significant $(p<0.01)$ associations [44]. An improvement in fall risk was demonstrated in institutionalized women following a stroke with vitamin D supplementation who had low serum concentrations at baseline [45]. Another study showed significant reduction in fall risk in patients with vascular Parkinsonism [46]. It has further been demonstrated that treatment with alfacalcidol can increase muscle balance and power resulting in decreased risk of falls [47]. An additional study supported this claim [48]. On the contrary there have been studies that have shown no benefit in vitamin D supplementation and reduced fall risk [49].

Movement, stability, and falls go hand in hand. Osteoporotic fractures have a significant effect on movement, especially in the elderly population. Treatment of these fractures lies largely in prevention including screening and appropriate intake of vitamin $\mathrm{D}$ and calcium [50]. The use of vitamin $\mathrm{D}$ in movement disorders has also been implicated. Automatic postural control was shown to be correlated with vitamin D concentrations [51]. The association of Parkinson's disease severity with vitamin D concentrations was demonstrated in the same study. Evidence is lacking to support the use of vitamin D in treatment of Alzheimer's disease [52,53], but one recent study showed vitamin $\mathrm{D}$ intake to be associated with decreased risk of developing the disease in older women [54].

The overwhelming majority of recent data supports the use of vitamin $\mathrm{D}$ as treatment for certain movement disorders and to reduce fall risk. Vitamin D is already used in prevention of osteoporotic fractures and at least one phase III trial tested the use of vitamin D in prevention of falls [55]. The clinical application of vitamin D in conditions affecting movement is rapidly increasing and has the potential to have some major effects on the quality of life of patients living with these conditions.

\section{Vitamin D and Disease}

\section{Cardiovascular illness}

The role of vitamin D in Cardiovascular Disease (CVD) is debated among researchers. Vitamin D deficiency is associated with increased risk of mortality according to the National Health and Nutrition Examination Survey III (NHANES III) [35]. Vitamin D deficiency has also been linked to hypertension, diabetes, and insulin resistance, which are known risk factors for CVD. Groups at greater risk of becoming vitamin D deficient include older adults, women, African Americans, diabetics, current smokers, and high Body Mass Indices (BMI) [56]. One in three deaths were attributed to cardiovascular disease in 2009; however, the role that vitamin $\mathrm{D}$ deficiency plays in these deaths cannot be inferred. The association of cardiovascular mortality with 25-hydroxyvitamin D concentration may not be a causal relationship, but simply a reflection of the underlying health of the individuals of this group [35].

There is still more to understand about the relationship between 25-ydroxyvitamin D serum concentrations and blood pressure; although, it is known that vitamin D plays a role in the control of the Renin-Angiotensin-Aldosterone System (RAAS) and indirectly regulates intracellular calcium levels, which mutually work on smooth muscle vascular tone [35]. Two recent randomized, doubleblind, placebo-controlled trials demonstrated that cholecalciferol administered during the winter months was able to significantly reduce systolic blood pressure [57,58]. No significant change was noted in diastolic blood pressure. Another recent trial demonstrated that vitamin D produced a short-term decrease in blood pressure [59]. Comparatively, a cross-sectional study and a longitudinal, populationbased multipurpose study showed no correlation between vitamin $\mathrm{D}$ levels and blood pressure [60-62]. Another cross-sectional study did not support a correlation with vitamin D levels and blood pressure [63].

Although vitamin $\mathrm{D}$ therapy may improve muscle function and reduce cardiac remodeling [35], there is still much to learn regarding its ability to improve health outcomes for patients suffering from heart failure. One randomized control trial demonstrated improved B-type naturetic peptide after a 10 week treatment regimen of 10,000 IU ergocalciferol compared to placebo [35]. An observational study demonstrated that vitamin D3 supplementation over one year did not significantly change markers of cardiovascular disease, including: total HDL and LDL cholesterol, triglycerides, APO A-1, insulin resistance or inflammatory markers [64]. Another trial supported the correlation between severe vitamin D deficiency and cardiovascular mortality in hospitalized patients [65].

The most recent data seems to support the use of vitamin D treatment in hypertensive patients. While different analogs of vitamin D 
have been clinically tested, the efficacies have not been fully determined. The future for use of vitamin D as treatment for cardiovascular illness is promising, but more trials are necessary to solidify its clinical purpose. More confirmatory data is necessary in order to discern the role that vitamin $\mathrm{D}$ can play in patients with heart disease.

\section{Cancer therapeutic}

The hormonally active form of vitamin $\mathrm{D}$, calcitriol, demonstrates anti-proliferative effects in vitro by promoting differentiation in a variety of cancer cell types including prostate, breast, colon, skin, and hematological cells [66-68]; however, there remains much debate on the efficacy of vitamin D on reducing cancer risk and use as a cancer treatment [69]. In addition to the tissues previously mention, VDR is expressed in pancreatic islet cells, skin keratinocytes, mammary glands and other reproductive tissues.

Ubiquitous expression of VDR in multiple human tissues implicated in cancer development has made vitamin $\mathrm{D}$ a therapeutic target of interest. Clinical trials assessing the effectiveness of vitamin D have been conflicting. It has been suggested, one reason for the conflict may relate to the stage of disease when vitamin $d$ treatment is initiated [69]. Vitamin D clinical trials involving patients with advanced stage disease were largely unsuccessful. Conversely, in a recent randomized clinical trial, vitamin D3 was shown to reduce prostate-specific antigen (PSA) in two dosing groups $(10,000 \mathrm{IU} / \mathrm{d}, \mathrm{p}=0.04$ and $40,000 \mathrm{IU} / \mathrm{d}, \mathrm{p}=0.19)$ and serum PTH in the highest dosing group $(40,000 \mathrm{IU} / \mathrm{d}, \mathrm{p}<0.0001)$ in men with localized prostate cancer [70]. One remaining concern is that the use of high dose vitamin D may result in hypercalcaemia; however, controlled regulation of the hydroxylases involved in the metabolism of vitamin D may reduce this risk.

\section{Diabetes control}

The effect of vitamin D on glycemic control is still being discovered. There has been some debate about the role of vitamin $\mathrm{D}$ in the onset and treatment of diabetes $[35,71,72]$, but recent studies are promising for its use in glycemic control. There have been numerous clinical trials that have successfully demonstrated its role. One study concluded that if patients consumed vitamin D-fortified yogurt twice a day for 12 weeks a significant improvement in glucose control was noted [73]. A meta-analysis found that there was a $55 \%$ reduction in risk of diabetes in patients with high serum 25-dihydroxyvitamin $\mathrm{D}$ concentration [74]. Another study showed a reduction of insulin resistance in south Asian women upon supplementation with vitamin D [75]. A recent prospective study also showed improvements in glycemic control with supplementation of vitamin D in Type 1 diabetic patients [76].

The pathogenesis of diabetes driven by insulin resistance or altered $\beta$-cell function has been linked to vitamin $\mathrm{D}$ deficiency in two recent studies [77,78]. In addition 1,25-dihydroxyvitamin $\mathrm{D}$ has been shown to play a significant role in improving insulin sensitivity in critical tissues including liver, skeletal muscle, and adipose tissue, along with enhancing $\beta$-cell function [71]. Animal and human models have also demonstrated a correlation between vitamin D deficiency and Type 1 Diabetes [71,72]. Evidence continues to associate polymorphisms in the genes of vitamin $\mathrm{D}$ binding protein, VDR, and vitamin $\mathrm{D}$ 1a-hydroxylase with pathogenesis of insulin resistance [71,72].

Despite the overwhelming data to support vitamin $\mathrm{D}$ in diabetes, there have still been studies that show no benefit of vitamin D supplementation in diabetic patients $[79,80]$. The benefit of vitamin $\mathrm{D}$ for the treatment of diabetes is becoming clearer, although more studies are required to determine standard dosing. Additional clinical trials will reveal a more in depth role for vitamin $\mathrm{D}$ in the treatment of diabetes.

\section{Conclusion}

The clinical role of vitamin D for treatment of non-bone diseases is still being evaluated. The top two causes of death, heart disease and cancer, are among the conditions for which vitamin $\mathrm{D}$ treatment is being considered. Vitamin D appears to play a significant role in many conditions associated with aging including cognition, depression, cancer, diabetes and cardiovascular disease. While the vitamin $\mathrm{D}$ data is more established concerning its association with depression, cognition and diabetes, conflict still remains in the role vitamin D plays in cancer and cardiovascular disease. Additional trials are needed to establish whether vitamin $\mathrm{D}$ therapy can treat or prevent these conditions in older adults. Because the amount and type of vitamin D therapy has varied substantially among prior clinical trials, future studies should focus vitamin $\mathrm{D}$ therapy on correcting vitamin $\mathrm{D}$ deficiency or maintaining serum vitamin $\mathrm{D}$ levels at a specific goal. This will allow more individualized therapy, which is necessary given the variability in individual vitamin $\mathrm{D}$ levels. If successful, vitamin $\mathrm{D}$ treatment could be an inexpensive therapy to reduce morbidity and mortality and improve quality of life for older adults.

\section{References}

1. Holick MF (1981) The cutaneous photosynthesis of previtamin D3: a unique photoendocrine system. J Invest Dermatol 77: 51-58.

2. Brown AJ, Dusso A, Slatopolsky E (1999) Vitamin D. Am J Physiol 277: 157175.

3. Eyles DW, Smith S, Kinobe R, Hewison M, McGrath JJ (2005) Distribution of the vitamin $\mathrm{D}$ receptor and 1 alpha-hydroxylase in human brain. $\mathrm{J}$ Chem Neuroanat 29: 21-30.

4. Heaney RP, Davies KM, Chen TC, Holick MF, Barger-Lux MJ (2003) Human serum 25-hydroxycholecalciferol response to extended oral dosing with cholecalciferol. Am J Clin Nutr 77: 204-210.

5. Christakos S, Dhawan P, Ajibade D, Benn BS, Feng J, et al. (2010) Mechanisms involved in vitamin D mediated intestinal calcium absorption and in non-classical actions of vitamin D. J Steroid Biochem Mol Biol 121: 183-187.

6. Ding C, Gao D, Wilding J, Trayhurn P, Bing C (2012) Vitamin D signalling in adipose tissue. Br J Nutr 108: 1915-1923.

7. Verstuyf A, Carmeliet G, Bouillon R, Mathieu C (2010) Vitamin D: a pleiotropic hormone. Kidney Int 78: 140-145.

8. Van Cromphaut SJ, Dewerchin M, Hoenderop JG, Stockmans I, Van Herck E, et al. (2001) Duodenal calcium absorption in vitamin D receptor-knockout mice: functional and molecular aspects. Proc Natl Acad Sci USA 98: 13324-13329.

9. Dusso AS, Thadhani R, Slatopolsky E (2004) Vitamin D receptor and analogs. Semin Nephrol 24: 10-16.

10. Meyer MB, Goetsch PD, Pike JW (2012) VDR/RXR and TCF4/i²-catenin cistromes in colonic cells of colorectal tumor origin: impact on c-FOS and c-MYC gene expression. Mol Endocrinol 26: 37-51.

11. Kizildag S, Ates $\mathrm{H}$, Kizildag $\mathrm{S}$ (2010) Treatment of K562 cells with 1,25-dihydroxyvitamin D3 induces distinct alterations in the expression of apoptosis-related genes BCL2, BAX, BCLXL, and p21. Ann Hematol 89: 1-7.

12. De Vita F, Lauretani F, Bauer J, Bautmans I, Shardell M, et al. (2014) Relationship between vitamin $\mathrm{D}$ and inflammatory markers in older individuals. Age (Dordr) 36: 9694.

13. Orme RP, Bhangal MS, Fricker RA (2013) Calcitriol imparts neuroprotection in vitro to midbrain dopaminergic neurons by upregulating GDNF expression. PLoS One 8: 62040.

14. Holmøy T, Moen SM (2010) Assessing vitamin D in the central nervous system. Acta Neurol Scand Suppl: 88-92.

15. Wilkins CH, Birge SJ, Sheline YI, Morris JC (2009) Vitamin D deficiency is associated with worse cognitive performance and lower bone density in older African Americans. J Natl Med Assoc 101: 349-354. 
16. Wilkins $\mathrm{CH}$, Sheline YI, Roe CM, Birge SJ, Morris JC (2006) Vitamin D deficiency is associated with low mood and worse cognitive performance in older adults. Am J Geriatr Psychiatry 14: 1032-1040.

17. Schlögl M, Holick MF (2014) Vitamin D and neurocognitive function. Clin Interv Aging 9: 559-568.

18. Stumpf WE, O'Brien LP (1987) 1,25 (OH)2 vitamin D3 sites of action in the brain. An autoradiographic study. Histochemistry 87 : 393-406

19. Eyles D, Brown J, Mackay-Sim A, McGrath J, Feron F (2003) Vitamin D3 and brain development. Neuroscience 118: 641-653.

20. Musiol IM, Stumpf WE, Bidmon HJ, Heiss C, Mayerhofer A, et al. (1992) Vitamin $D$ nuclear binding to neurons of the septal, substriatal and amygdaloid area in the Siberian hamster (Phodopus sungorus) brain. Neuroscience 48: 841-848.

21. Ichimiya Y, Emson PC, Mountjoy CQ, Lawson DE, Heizmann CW (1988) Loss of calbindin-28K immunoreactive neurones from the cortex in Alzheimer-type dementia. Brain Res 475: 156-159.

22. Molinari S, Battini R, Ferrari S, Pozzi L, Killcross AS, et al. (1996) Deficits in memory and hippocampal long-term potentiation in mice with reduced calbindin D28K expression. Proc Natl Acad Sci USA 93: 8028-8033.

23. Sonnenberg J, Luine VN, Krey LC, Christakos S (1986) 1,25-Dihyroxyvitamin D3 treatment results in increased choline acetyltransferase activity in specific brain nuclei. Endocrinology 118: 1433-1439.

24. Altemus KL, Finger S, Wolf C, Birge SJ (1987) Behavioral correlates of vitamin D deficiency. Physiol Behav 39: 435-440.

25. Kipen E, Helme RD, Wark JD, Flicker L (1995) Bone density, vitamin D nutrition, and parathyroid hormone levels in women with dementia. J Am Geriatr Soc 43 : 1088-1091.

26. Ogihara T, Miya K, Morimoto S (1990) Possible participation of calciumregulating factors in senile dementia in elderly female subjects. Gerontology 36 Suppl 1: 25-30.

27. Sato Y, Asoh T, Oizumi K (1998) High prevalence of vitamin D deficiency and reduced bone mass in elderly women with Alzheimer's disease. Bone 23: 555557

28. Jorde R, Waterloo K, Saleh F, Haug E, Svartberg J (2006) Neuropsychological function in relation to serum parathyroid hormone and serum 25-hydroxyvitamin D levels. The Tromsø study. J Neurol 253: 464-470.

29. van der Schaft J, Koek HL, Dijkstra E, Verhaar HJ, van der Schouw YT, et al. (2013) The association between vitamin D and cognition: a systematic review. Ageing Res Rev 12: 1013-1023.

30. Balion C, Griffith LE, Strifler L, Henderson M, Patterson C, et al. (2012) Vitamin $D$, cognition, and dementia: a systematic review and meta-analysis. Neurology 79: 1397-1405.

31. Przybelski RJ, Binkley NC (2007) Is vitamin D important for preserving cognition? A positive correlation of serum 25-hydroxyvitamin D concentration with cognitive function. Arch Biochem Biophys 460: 202-205.

32. Inderjeeth CA, Glennon D, Petta A, Soderstrom J, Boyatzis I, et al. (2007) Vitamin $\mathrm{D}$ and muscle strength in patients with previous fractures. N Z Med J 120: 2730 .

33. Annweiler C, Schott AM, Montero-Odasso M, Berrut G, Fantino B, et al. (2010) Cross-Sectional Association Between Serum Vitamin D Concentration and Walking Speed Measured at Usual and Fast Pace Among Older Women: The EPIDOS Study. J Bone Miner Res 25: 1858-1866.

34. Oren DA, Schulkin J, Rosenthal NE (1994) 1,25 (OH)2 vitamin D3 levels in seasonal affective disorder: effects of light. Psychopharmacology (Berl) 116: $515-516$

35. Haines ST, Park SK (2012) Vitamin D supplementation: what's known, what to do, and what's needed. Pharmacotherapy 32: 354-382.

36. Lapid MI, Cha SS, Takahashi PY (2013) Vitamin D and depression in geriatric primary care patients. Clin Interv Aging 8: 509-514.

37. Schneider B, Weber B, Frensch A, Stein J, Fritz J (2000) Vitamin D in schizophrenia, major depression and alcoholism. J Neural Transm 107: 839842

38. Kenny AM, Biskup B, Robbins B, Marcella G, Burleson JA (2003) Effects of vitamin $\mathrm{D}$ supplementation on strength, physical function, and health perception in older, community-dwelling men. J Am Geriatr Soc 51: 1762-1767.
39. Hoogendijk WJ, Lips P, Dik MG, Deeg DJ, Beekman AT, et al. (2008) Depression is associated with decreased 25-hydroxyvitamin $D$ and increased parathyroid hormone levels in older adults. Arch Gen Psychiatry 65: 508-512.

40. Cole RJ, Kripke DF, Wisbey J, Mason WJ, Gruen W, et al. (1995) Seasonal variation in human illumination exposure at two different latitudes. J Biol Rhythms 10: 324-334.

41. Spoont MR, Depue RA, Krauss SS (1991) Dimensional measurement of seasonal variation in mood and behavior. Psychiatry Res 39: 269-284

42. Gloth FM 3rd, Alam W, Hollis B (1999) Vitamin D vs broad spectrum phototherapy in the treatment of seasonal affective disorder. J Nutr Health Aging 3: 5-7.

43. Lansdowne AT, Provost SC (1998) Vitamin D3 enhances mood in healthy subjects during winter. Psychopharmacology (Berl) 135: 319-323.

44. Peterson A, Mattek N, Clemons A, Bowman GL, Buracchio T, et al. (2012) Serum vitamin $D$ concentrations are associated with falling and cognitive function in older adults. J Nutr Health Aging 16: 898-901.

45. Verheyden GS, Weerdesteyn V, Pickering RM, Kunkel D, Lennon S, et al (2013) Interventions for preventing falls in people after stroke. Cochrane Database Syst Rev 5: CD008728.

46. Sato Y, Iwamoto J, Honda Y, Amano N (2013) Vitamin D reduces falls and hip fractures in vascular Parkinsonism but not in Parkinson's disease. Ther Clin Risk Manag 9: 171-176.

47. Dukas L, Schacht E, Runge M, Ringe JD (2010) Effect of a six-month therapy with alfacalcidol on muscle power and balance and the number of fallers and falls. Arzneimittelforschung 60: 519-525.

48. Schacht E, Ringe JD (2012) Alfacalcidol improves muscle power, muscle function and balance in elderly patients with reduced bone mass. Rheumatol Int 32: 207-215.

49. Sanders KM, Stuart AL, Williamson EJ, Simpson JA, Kotowicz MA, et al. (2010) Annual high-dose oral vitamin $D$ and falls and fractures in older women: a randomized controlled trial. JAMA 303: 1815-1822.

50. Wilkins $\mathrm{CH}$ (2007) Osteoporosis screening and risk management. Clin Interv Aging 2: 389-394.

51. Peterson AL, Mancini M, Horak FB (2013) The relationship between balance control and vitamin D in Parkinson's disease-a pilot study. Mov Disord 28 1133-1137.

52. Stein MS, Scherer SC, Ladd KS, Harrison LC (2011) A randomized controlled trial of high-dose vitamin D2 followed by intranasal insulin in Alzheimer's disease. J Alzheimers Dis 26: 477-484.

53. Evatt ML, Delong MR, Khazai N, Rosen A, Triche S, et al. (2008) Prevalence of vitamin $d$ insufficiency in patients with Parkinson disease and Alzheime disease. Arch Neurol 65: 1348-1352.

54. Annweiler C, Rolland Y, Schott AM, Blain H, Vellas B, et al. (2012) Highe vitamin $D$ dietary intake is associated with lower risk of alzheimer's disease: a 7-year follow-up. J Gerontol A Biol Sci Med Sci 67: 1205-1211.

55. López-Torres Hidalgo J; ANVITAD Group (2011) Prevention of falls and fractures in old people by administration of calcium and vitamin D, randomized clinical trial. BMC Public Health 11: 910.

56. Melamed ML, Michos ED, Post W, Astor B (2008) 25-hydroxyvitamin D levels and the risk of mortality in the general population. Arch Intern Med 168: 1629 1637

57. Forman JP, Scott JB, Ng K, Drake BF, Suarez EG, et al. (2013) Effect of vitamin $\mathrm{D}$ supplementation on blood pressure in blacks. Hypertension 61: 779-785.

58. Larsen T, Mose FH, Bech JN, Hansen AB, Pedersen EB (2012) Effect of cholecalciferol supplementation during winter months in patients with hypertension: a randomized, placebo-controlled trial. Am J Hypertens 25 1215-1222.

59. Judd SE, Raiser SN, Kumari M, Tangpricha V (2010) 1,25-dihydroxyvitamin D3 reduces systolic blood pressure in hypertensive adults: a pilot feasibility study. J Steroid Biochem Mol Biol 121: 445-447.

60. Snijder MB, Lips P, Seidell JC, Visser M, Deeg DJ, et al. (2007) Vitamin D status and parathyroid hormone levels in relation to blood pressure: a populationbased study in older men and women. J Intern Med 261: 558-565.

61. Jorde R, Bonaa KH (2000) Calcium from dairy products, vitamin D intake, and blood pressure: the Tromso Study. Am J Clin Nutr 71: 1530-1535. 
62. Jorde R, Figenschau Y, Emaus N, Hutchinson M, Grimnes G (2010) Serum 25-hydroxyvitamin $D$ levels are strongly related to systolic blood pressure but do not predict future hypertension. Hypertension 55: 792-798

63. Jorde R, Sneve M, Torjesen P, Figenschau $Y$ (2010) No improvement in cardiovascular risk factors in overweight and obese subjects after supplementation with vitamin D3 for 1 year. J Intern Med 267: 462-472.

64. Wood AD, Secombes KR, Thies F, Aucott L, Black AJ, et al. (2012) Vitamin D3 supplementation has no effect on conventional cardiovascular risk factors: a parallel-group, double-blind, placebo-controlled RCT. J Clin Endocrinol Metab 97: $3557-3568$

65. Correia LC, Sodré F, Garcia G, Sabino M, Brito M, et al. (2013) Relation of severe deficiency of vitamin $D$ to cardiovascular mortality during acute coronary syndromes. Am J Cardiol 111: 324-327.

66. Abe E, Miyaura C, Sakagami H, Takeda M, Konno K, et al. (1981) Differentiation of mouse myeloid leukemia cells induced by 1 alpha,25-dihydroxyvitamin D3. Proc Natl Acad Sci USA 78: 4990-4994.

67. Colston K, Colston MJ, Feldman D (1981) 1,25-dihydroxyvitamin D3 and malignant melanoma: the presence of receptors and inhibition of cell growth in culture. Endocrinology 108: 1083-1086.

68. Lee LR, Teng PN, Nguyen H, Hood BL, Kavandi L, et al. (2013) Progesterone Enhances Calcitriol Antitumor Activity by Upregulating Vitamin D Receptor Expression and Promoting Apoptosis in Endometrial Cancer Cells. Cancer Prev Res (Phila) 6: 731-743.

69. Plum LA, DeLuca HF (2010) Vitamin D, disease and therapeutic opportunities. Nat Rev Drug Discov 9: 941-955.

70. Wagner D, Trudel D, Van der Kwast T, Nonn L, Giangreco AA, et al. (2013) Randomized clinical trial of vitamin D3 doses on prostatic vitamin D metabolite levels and ki67 labeling in prostate cancer patients. J Clin Endocrinol Metab98: 1498-1507.

71. Sung CC, Liao MT, Lu KC, Wu CC (2012) Role of vitamin D in insulin resistance. J Biomed Biotechnol 2012: 634195.
72. Chakhtoura M, Azar ST (2013) The role of vitamin d deficiency in the incidence, progression, and complications of type 1 diabetes mellitus. Int $\mathrm{J}$ Endocrino 2013: 148673

73. Nikooyeh B, Neyestani TR, Farvid M, Alavi-Majd H, Houshiarrad A, et al (2011) Daily consumption of vitamin D- or vitamin D + calcium-fortified yogurt drink improved glycemic control in patients with type 2 diabetes: a randomized clinical trial. Am J Clin Nutr 93: 764-771.

74. Parker J, Hashmi O, Dutton D, Mavrodaris A, Stranges S, et al. (2010) Levels of vitamin $\mathrm{D}$ and cardiometabolic disorders: systematic review and meta-analysis. Maturitas 65: 225-236.

75. von Hurst PR, Stonehouse W, Coad J (2010) Vitamin D supplementation reduces insulin resistance in South Asian women living in New Zealand who are insulin resistant and vitamin $D$ deficient - a randomised, placebo-controlled trial. $\mathrm{Br} \mathrm{J}$ Nutr 103: 549-555.

76. Aljabri KS, Bokhari SA, Khan MJ (2010) Glycemic changes after vitamin D supplementation in patients with type 1 diabetes mellitus and vitamin D deficiency. Ann Saudi Med 30: 454-458.

77. Deleskog A, Hilding A, Brismar K, Hamsten A, Efendic S, et al (2012) Low serum 25-hydroxyvitamin $D$ level predicts progression to type 2 diabetes in individuals with prediabetes but not with normal glucose tolerance. Diabetologia 55: 1668-1678.

78. Forouhi NG, Ye Z, Rickard AP, Khaw KT, Luben R, et al. (2012) Circulating 25-hydroxyvitamin $D$ concentration and the risk of type 2 diabetes: results from the European Prospective Investigation into Cancer (EPIC)-Norfolk cohort and updated meta-analysis of prospective studies. Diabetologia 55: 2173-2182.

79. Pittas AG, Chung M, Trikalinos T, Mitri J, Brendel M, et al. (2010) Systematic review: Vitamin D and cardiometabolic outcomes. Ann Intern Med 152: $307-$ 314

80. Jorde R, Figenschau Y (2009) Supplementation with cholecalciferol does not improve glycaemic control in diabetic subjects with normal serum 25-hydroxyvitamin D levels. Eur J Nutr 48: 349-354. 